\title{
Development of E-Book-Based Discovery Learning to Improve Motivation and Learning Outcomes on Accounting Education University Of Flores East Nusa Tenggara
}

\author{
Sofia Leki Bau ${ }^{1}$, Sunardi ${ }^{1}$, Sudiyanto $^{1}$ \\ ${ }^{1}$ Universitas Sebelas Maret \\ e-mail: Sofialekibau@gmail.com
}

\begin{abstract}
This study aimed to develop e-book based Discovery Learning and improve motivation \& learning outcomes of accessible offline e-Book through windows or android smartphone. This research was conducted for the second semester students of Economics Education Study Program especially in learning accounting basics at Flores University, East Nusa Tenggara. The method in this research was the research and development of the products based on the findings of the field test. The model was the development of procedural models adaptation and modified Borg and Gall consisting of three phases; the preliminary phase (research \& information collection and Planning), the development phase (Development of Preliminary Form of Product, Preliminary Field Testing, Main Product Revision, Testing and Operational Field Main Product Revision), and the evaluation phase (Field Operational Testing and Final Product). The technique of analyzing the data was using qualitative analysis. The result of the research showed that the need for e-book based discovery learning was effective and efficient in increasing the students' motivation and learning outcomes at Economics Education Study Program, Flores University.
\end{abstract}

\section{INTRODUCTION}

Learning process in College requires students to be active. Therefore, the students should not only observe what the lecturer explains, but also need references to explore sciences in order to optimize the students' critical thinking ability. The process of active learning is in accordance with the constructivism view of learning as a process in which the learner actively builds new ideas or concepts. [1] Stated that constructivist theory emphasizes the provision of opportunities for the students to make judgments and interpretations of their own situations based on their previous knowledge and experiences called "constructivism" (p. 2). This is based on active involvement or students' participation in the learning process. Furthermore, [2] stated that the constructivist approach emphasizes how the students construct their own knowledge based on the given problem (p. 37). In other word, knowledge can be shaped by the students on their mind after the existence of the interaction with the environment. 
Multimedia-based learning is a learning that stimulates students to be active. [3] stated that multimedia combines a variety of digital media types, such as: text, picture (visual), audio and video into a multi-sensory integrated interactive application or presentation to deliver message or information to the audiences, while according to [4], multimedia is the combination of several different technologies united into a set (ware). Multimedia can be an effective learning media in delivering information as it enables the lecturer to deliver information in some media through audio, text, animation, video, picture (visual) and etc. The combination of various media enables the creation of environment stimulating learning interest and the memorization of information conveyed [5]. One of multimedia findings in education is e-Book media.

[6] said that e-Book is a hardware and software system that can present information in the form of the text in large number to the users and enable the users to browse information contained. E-Book also features and combines text, graphic, audio, and even video into digital presentation contained in a unity [7]. Most students of mathematics postgraduate program use mobile e-Book to search for information in their research activities in order to get benefits (science) [8]. Currently, the multimedia (e-Book) use is very common in education. It is consistent with [9] that the objective of learning with multimedia (e-Book) aid is to make the students participate actively in learning, to make communication more effective, to facilitate forum, to increase learning interest and motivation of the students. Learning motivation is one basis of the students' quality. When there is no learning motivation, method, media, and way used to teach will provide less expected result. According to [10], motivation is an internal condition generating, directing, and supporting the students' behaviors. Many authors [11]; [12]; [13]; [14] showed that the use of appropriate learning method can improve learning motivation and use considerable effects on the acquisition of knowledge and academic achievement.

Young generation in the $21^{\text {st }}$ century should be supported with novelties like e-Book multimedia use in growing learning motivation during learning process. Education evolution is useful to attract the students to learn using e-Book as it is considered as a unique and challenging thing. Accounting e-book will be presented more effectively when it is added with appropriate learning method. The learning method is one of the external factors affecting the students' learning outcomes. The use of appropriate learning method leads to higherquality e-book. E-Book is expected to help the lecturers' creativities in using an appropriate media, not using out-of-date learning method. The purpose is to make the students more active. [15] said that active learning process includes discovery learning. Discovery learning is a mental process in which the students can assimilate a concept or principle. Mental process includes observing, absorbing, understanding, categorizing, predicting, explaining, measuring, concluding, etc. [16]. According to [15], discovery learning is the one emphasizing on the mastery of certain skill through repeated exercises and practices. 


\section{METHOD}

The method employed in this research was research and development yielding the product based on the finding in field test. The development model used was Borg and Gall's modified procedural model cited from [17], consisting of three stages: preliminary (research \& information collection and Planning), development (Develop Preliminary Form of Product, Preliminary Field Testing, Main Product Revision, Main field Testing and Operational Product Revision), and evaluation (Operational Field Testing and Final Product) stages. Technique of analyzing data used was qualitative analysis, with preliminary study.

Preliminary study was conducted in Economics Education Study Program of Flores University, in which the author conducted library study and field study using an empirical study. Literature study was carried out by studying the literatures relevant to theories, concepts and relevant previous studies to support the study in the field. Literature study is the one related to e-Book based Discovery Learning to improve learning motivation and learning outcomes. The techniques of collecting data in this research were observation, interview, questionnaire (teacher analysis, curriculum, school infrastructure, student characteristics and need analysis), and documentation. Data and information obtained were taken into accounts in developing e-Book learning media. The results of the research found that the economics education study program needs a module/electronic book that can help the students and lecturers in the learning process.

\section{DISCUSSION}

Economic Education Study Program is one of 15 Study Programs existing at Flores University. Observation was conducted by the researcher from January to February 2017 identifying problems in learning process. The occurring phenomena were that learning was still lecturers' center; lecturers still used conventional model (lecturing, debriefing, and discussion), and module used by lecturers was expository (explaining module only rather than solving problems and being outdated. Those problems lead the students to have the low critical thinking ability. Therefore, the students were passive in learning process. It made the students having low learning motivation and outcomes. The occurring problems in Basic Accounting course characterized with the End-Semester Exam Scores of Economic Education Study Program of Flores University were still less optimal viewed from the mean scores of 73, 71, 64, and 71, 52 for Class A, B, and C respectively at the third semester, with minimum passing criteria of 75 . The scores of the final exam can be seen in the following table. 
TABLE I. FINAL EXAM SCORE VALUE TABLE YEAR 2015/2016

\begin{tabular}{|c|c|c|c|}
\hline \multirow{2}{*}{ Number } & \multicolumn{3}{|c|}{ Class } \\
\cline { 2 - 4 } & $\mathrm{A}$ & $\mathrm{B}$ & $\mathrm{C}$ \\
\hline 1. & 73 & 70 & 70 \\
2. & 70 & 72 & 73 \\
3. & 75 & 71 & 70 \\
4. & 72 & 75 & 72 \\
5. & 75 & 70 & 70 \\
6. & 70 & 71 & 73 \\
7. & 73 & 70 & 70 \\
8. & 70 & 72 & 72 \\
9. & 70 & 70 & 70 \\
10. & 72 & 71 & 72 \\
11. & 80 & 70 & 70 \\
12. & 70 & 75 & 75 \\
13. & 70 & 70 & 70 \\
14. & 70 & 74 & 73 \\
15. & 72 & 70 & 70 \\
16. & 70 & 74 & 72 \\
17. & 74 & 71 & 70 \\
18. & 70 & 70 & 75 \\
19. & 70 & 72 & 70 \\
20. & 80 & 73 & 72 \\
21. & 70 & 70 & 70 \\
22. & 70 & 73 & 72 \\
23. & 80 & 72 & 70 \\
24. & 70 & 70 & 80 \\
25. & 70 & 72 & \\
\hline Mean & 73 & 71,64 & \\
\hline Source: Author Data & & & 70 \\
\hline
\end{tabular}

The result of questionnaire distributed to the $3^{\text {rd }}$ semester students of Economic Education Study Program showed that $70.66 \%$ students did not understand the Basic Accounting course. $85.33 \%$ students stated that economic education study program was not their main concentration when they enrolled at college. $90.66 \%$ students stated that they understood the materials and the contents of the book of Basic Accounting very well. The result of analysis of questionnaire can be seen in the following table. 
TABLE II. RESULT OF ANALYSIS OF QUESTIONNAIRE OF STUDENTS' RESPONSES

\begin{tabular}{|r|l|l|l|l|l|}
\hline \multicolumn{1}{|c|}{ No } & \multicolumn{1}{|c|}{ Question } & \multicolumn{3}{|c|}{ Scoring Scale } \\
\cline { 3 - 6 } & & $\sum \mathrm{ni}$ & $\sum \mathrm{N}$ & $100 \%$ & Score \\
\hline 2. & $\begin{array}{l}\text { After studying the basics of accounting, I am } \\
\text { very well acquainted }\end{array}$ & 53 & 75 & 100 & 70.66 \\
\hline 2. & $\begin{array}{l}\text { Department of Economic Education is my first } \\
\text { choice when enrolling in college }\end{array}$ & 64 & 75 & 100 & 85.33 \\
\hline 3. & $\begin{array}{l}\text { The condition of the class during the lecture of } \\
\text { the basics of accounting takes place very } \\
\text { conducive (comfortable) }\end{array}$ & 7 & 75 & 100 & 9.33 \\
\hline 4. & $\begin{array}{l}\text { I have a book / module as a learning resource } \\
\text { (private property) }\end{array}$ & 5 & 75 & 100 & 6.66 \\
\hline 5. & $\begin{array}{l}\text { I can understand well the book is owned, able } \\
\text { to learn independently }\end{array}$ & 68 & 75 & 100 & 90.66 \\
\hline
\end{tabular}

Source: Author Data

Considering the result of interview with the $3^{\text {rd }}$ semester students of Economic Education Study Program at Flores University, it can be concluded that the teaching materials of basic accounting course given by the lecturers were not understood. The students were interested in learning the basic accounting course by using multimedia. Analyzing from the observations, interviews, and analysis of the needs of the students of Economic Education Study Program at Flores University, the multimedia aid of the teaching materials should be added by using the learning method that will improve the students' learning motivation and outcomes. In this digitalization era, the lecturers are required to use an up-date learning media attracting the students' interest in learning process. In addition, the lecturers should provide learning methods enabling the students to select, find, and develop their knowledge along with the lecturers. The appropriate learning method can stimulate the students' understanding to think critically, to solve problems themselves, and to give the students the opportunities in finding new ideas in learning process. It makes the old learning paradigm becoming the new one in which the lecturers serve as facilitators and motivators. It is consistent with [18], learning is the acquisition of relatively permanent behavioral changes as the result of practices or experiences, or learning is the process in responding to, as the result of special practices (p. 66).

Furthermore, there was another problem. $38.31 \%$ students of Economic Education Study Program at Flores University were selected from Natural Science, language and other majors rather than Social Science/Accounting major in Senior High School. Basic understanding on accounting is very important to the students, especially for those who never learn basic knowledge on accounting in Senior High School. This basic knowledge is useful to follow-up other accounting courses, such as: intermediate financial accounting 1, intermediate financial accounting 2, advanced accounting, etc. The students of Economic Education Study Program are candidates of teachers of accounting who should actually understand and master accounting in order to be able to implement it to their students. To address those problems, Discovery Learning-based e-Book is developed.

Indonesian Accounting Association (Ikatan Akuntansi Indonesia = IAI) has decided to converge completely the Standard Accounting Statement (Pernyataan Standar Akuntansi $=$ PSAK) with International Financial Reporting Standard (IFRS) 
in 2012. In the presence of such regulation, the learning materials of accounting in college should automatically follow the development by using IFRS. The lecturer of accounting is the one who plays a very important role in implementing IFRS in learning accounting. The development of e-Book for Basic Accounting course based on Discovery Learning is accompanied with IFRS. Therefore, it is very important and desirable recalling the lecturers with poor knowledge on IFRS. The lecturers should renew the contents of the course with the update materials. It is in line with [19] combining IFRS into the curriculum of college in which the adoption of IFRS encourages the active collaborative learning and develops basic skills including critical thinking and information literacy. [20] found that the convergence of IFRS and the adoption of IFRS occur at global scale as it is a standard or measure for financial report; IFRS is used globally in many countries; the adoption of IFRS uses positive effects in many countries compared with that before IFRS adoption and makes the financial market more competitive. [21] concluded that the development of a trading company accounting module should be adjusted with the information and the compatibility of IFRS to PSAK; additionally there should be field review on the implementation of existing trading company accounting practice module.

Discovery Learning based e-Book is a multimedia learning module consisting of text, picture, graphic, audio and video in the form of soft file published in digital form that can be read on computer or other electronic wares. E-book is a learning media, while Discovery Learning is a learning method. The main aspects supporting the quality of learning are learning media and method used in the learning process. In this case, a learning innovation like Discovery Learning based e-Book for basic accounting course is one answer to the problems occurring in Economic Education Study Program at Flores University. It is in line with [22] study that the use of eBook can improve quality \& function and help the students and lecturers in teaching and learning process. [23] showed that through applying independent learning system and learning model like e-Book, the students' understanding can be explored regarding the materials that the lecturer delivers in learning process. [24] concluded that the students responded positively to the application of Discovery Learning model and this model affected the students' learning outcomes.

E-book must have clear and ideal characteristics. According to [25], Characteristics of E-book are:

1) Clearly, the writing style and its contents,

2) In accordance with what is meant not at length,

3) It has sizes, such as: plain text, PDF (Portable Document Format), JPEG, LIT, Doc, HTML (Hyper Text Markup Language), Open Electronic Book Package Format.

According to [5] the characteristics of e-Book are:

1) A visual-based module that allows users to see the concept presented.

2) Contains teaching materials and a combination of learning methods that enable learners to learn at their own pace, ability to accept and understand lessons.

3) Encompass interactive features that will empower users to control the content of information flows and encourage students to be responsible for their own learning (p. 122).

According to [26], the main features of learning to discover (Discovery Learning) are:

1) Exploring and solving problems to create, combine, and generalize knowledge. 
2) Student centered

3) Activities to combine new knowledge and existing knowledge (p. 284).

According to [15], Discovery Learning is also known as constructivism learning. There are three characteristics of Discovery Learning:

1) Creation, integration and generalization of knowledge through exploration and problem solving in which students are not passive but rather active learners develop understanding and build broader application for skills through their involvement in activities where risk taking, problem solving, and examination of their unique experiences are required.

2) Learning process is driven by interest-based activities. The students are not locked into learning activities, but with the willingness of the students themselves.

3) Activities that seek to integrate new knowledge for the students to support instructions that enable them to use their own skills and experiences as a foundation so that they can form new perspectives and apply new knowledge ( $\mathrm{p}$. $314)$.

It can be concluded that the characteristics of Discovery Learning based e-book are 1) multimedia teaching material presented in soft file and downloadable through play store, 2) containing Discovery Learning method making the learning process student-center in which the students are active rather than passive, 3) developing broader understanding and building application for the students' skill through their participation in risk taking, problem solving, and unique experiences examination activities, 4) attracting the students to learning and finding new things that enable them to use their own skill and experiences as their foundation to create new perspectives and to apply new knowledge. Discovery Learning e-Book also has such advantages as it makes the learning process more joyful because this e-Book is accessible, portable in large number, relatively cheap, no large and big storage place, can be copied and pasted easily thereby triggering the students' activeness and creativity in solving problems independently and motivating the students to learn, leading to the improvement in learning outcomes.

Development model is Borg and Gall's modified procedural model [17], consisting of three stages: preliminary (research \& information collection and Planning), development (Develop Preliminary Form of Product, Preliminary Field Testing, Main Product Revision, Main field Testing and Operational Product Revision), and evaluation (Operational Field Testing and Final Product) stages. The article explains only preliminary and development stages, but the discussion of development stage is limited to Develop Preliminary Form of Product, Preliminary Field Testing, as explained below.

\section{Develop Preliminary Form of Product}

The preliminary design of e-Book is developed by taking the learning objective, material, and target of product user into account. The preliminary product development stage will yield a draft e-Book of basic accounting leaning containing text, video, audio, and picture (visual). 


\section{Preliminary Field Testing}

In this stage, the preliminary field testing is conducted to obtain data of preliminary qualitative evaluation on the draft product developed. The draft is validated (tested internally) by expert and practitioners. The result of validation conducted by expert and practitioners is then used to improve the product design to be a preliminary product that will be used in small-scale trial. The validator in research and development is as follows.

Subject of trial

\section{INTERNAL VALIDATION}

\section{Material Expert Validation}

In this case, the material expert will evaluate the content appropriateness of eBook designed. The aspects are assessed including material compatibility, standard competency, and basic competency and IFRS. The subject of trial for the material design expert in this research is accounting lecturers with the following qualifications: doctorate degree with more than 5-year teaching experience. It is carried out by submitting the product and questionnaire containing the questions about the appropriateness of material existing in Discovery Learning based e-Book to validate by materials experts. The further research summarizes the data obtained to be improved or revised corresponding to the materials experts' recommendation and input.

\section{Learning Media Expert Validation}

Media expert validation is intended to get assessment about the media developed in relation to the criteria of good learning media. The subject of teaching materials/eBook media development design expert trial consists of accounting lecturers with doctorate qualification, media expert coming from the profession related to education technology with more than 5-year teaching experience. It is carried out by submitting the product and instrument containing the questions about product design, to find out whether or not the teaching material has been consistent with learning design and character of Accounting Students.

\section{Practitioner Validation}

Practitioner validation aims to explore information about assessment and recommendation for the effectiveness of learning media, its implementation and feasibility. It is carried out by submitting the product and instrument containing the questions about product design, to find out whether or not the teaching material has been consistent with learning design and character of Accounting Students. 


\section{EXTERNAL VALIDATION}

External validation is conducted by the $3^{\text {rd }}$ semester students of Economic Education Study Program at Flores University, Ende. External validation is conducted to find out the validity and reliability of questionnaire and to find out validity, reliability, distinguishing factor, and difficulty level of test given to the students.

\section{CONCLUSION}

Based on the research conducted at Flores University, the following problems were found: learning was still lecturers-center, lecturers still used conventional model (lecturing, debriefing, and discussion), module used by the lecturers was expository (explaining module rather than solving problems and being outdated), and the students of Economic Education Study Program at Flores University were selected from natural science, language and other majors rather than social science/accounting major in Senior High School. Considering those problems occurring in Economic Education Study Program at Flores University, one of the solutions is the use of Discovery Learning based Basic Accounting e-book. The Discovery Learning based Basic Accounting e-book had been revised several times by experts, practitioners, and students. The purpose is to improve the students' learning motivation and outcomes effectively and efficiently in Economics Education Study Program at Flores University.

\section{REFERENCES}

[1] Irshad Hussain. (2012). Use of construtivitst Approach in higher Education: An Instructors' Observation,.3, (2), 179-184.

[2] John Abdi, M.Iklas, \& Marwan. (2013). Meningkatkan kemampuan siswa sekolah menengah atas dalam menyelesaikan soal matematika setara pisa melalui pendekatatan kontrrutivisme. 4 (1).

[3] Tolhurst, D. (1995). Hypertext, hypermedia, multimedia defined?. EducationalTechnology ,35 (3), 6-21.

[4] Fielman, T. (1997). Introduction to Digital Media. New York: Routledge.

[5] Neo, T., K., \& Neo, M. (2004). Classroom Inovation Enganging Student in Interactive Multimedia Learning. Campus - Wide Information Systems, 21 (3), 118-124.

[6] Borchers, J. O. (1999). Electronic Books: Definition, Genre, Interaction Design Pattern, Austria: Linz University.

[7] Hilgers M. G, Flachsbart B.B, \& Elrod C.C. (2012). Innovative Practice Collaborative International Education : reaching ascross borders multicultural education \& technology journals, 6 (1), 45-56.

[8] Letchumanan. M \& Muniandy. B. (2016)."How mathematics postgraduate students use mobile e-book? ".Library Hi Tech News, 33 (7), 6 - 7.

[9] Dryden, G, \& Vos, J. (2000). The Learning Revolution (buku 11). Terj. Word ++ Translation Service. Bandung : Kaifa.

[10] Glynn, S.M. and Koballa, T.R. (2006). Motivation to learn college science. Arlington. National Science Teachers Association Press.

[11] Garner, R. (1990), When children and adults do not use learning strategies: toward a theory of settings. Review of Educational Research, 60 (4), 517-29. 
[12] Paris, S.G. (1988). Models and metaphors of learning strategies, in Weinstein Learning and Study Strategies: Issues in Assessment, Instruction, and Evaluation. San Diego: Academic Press.

[13] Pintrich, P.R. and De Groot, E.V. (1990). Motivational and self-regulated learning components of classroom academic performance. Journal of Educational Psychology, 82 (1), 33-40.

[14] Pressley, M., Goodchild, F., Fleet, J., Zajchowski, R. and Evans, E.D. (1989). The challenges of classroom strategy instruction. Elementary School Journal, 89 (3), 31-42.

[15] Bicknell, T \& Hoffman, H. P.S. (2000). Elicit, Engage, Experience, Explore: Discovery Learning In Library Instruction. Reference Services Review, 28 (4), 313 - 322.

[16] Roestiyah, N.K. 2001. Strategi Belajar-Mengajar. Jakarta : Rineka Cipta.

[17] Sugiyono,(2015). Metode Penelitian Pendidikan. Bandung: Alfabeta.

[18] Syah, M. (2010). Psikologi Pendidikan: Dengan Pendekatan Baru. Edisi Revisi. Bandung: PT. Remaja Rosdakarya

[19] Allon. A. (2012). The IFRS Question To Adopt Or Not. Advances Is Accounting Education, 13 (4), 405-423.

[20] Moser, R. (2014). IFRS and convergence in China and the USA. Journal of Technology Management in China, 9 (1). 56 - 66.

[21] Riadi, R.M. \& Trisnawati, F. (2015). Pengembangan Bahan Ajar Praktik Akuntansi Perusahaan Dagang Untuk Meningkatkan Kompetensi Mahasiswa Pada Program Studi Pendidikan Ekonomi Fkip Ur. Pekbis Jurnal, 7 (1). 1-10.

[22] Lai, C. (2016). Integrating E-Books Into Science Teaching By Preservice Elementary School Teachers. Journal of Education in Science: Environment and Health (JESEH), 2(1), 57-66.

[23] Chen, H. Y. \& Jang, S.J. (2013). Exploring The Reasons For Using Electric Books And Technologic Pedagogical And Content Knowledge Of Taiwanese Elementary Mathematics And Science Teachers. Journal TOJET: Educational Technology, 12 (2), 131-141.

[24] Ismawati, D.A. \& Dwikoranto. (2015). Penerapan Model Pembelajaran Discovery Learning terhadap hasil belajar pada materi Fluida Statis di SMAN 1 Mojosari. Jurnal Inovasi Pendidikan Fisika (JIPK), 4 (3), 82-87.

[25] Sulaiman, S. (2010, 23 Juni). Mengenal Buku Elektronik (EBOOK). Diperoleh 1 April 2017dari sulaimansedulag. Blogspot.co.id/2010/06/ mengenal-buku-elektronik-e-book.html.

[26] Hosnan, M. \& Dipl, Ed. (2014) . Pendekatan Saintifik dan Kontekstual dalam pembelajaran abad 21. Jakarta : Ghalia Indonesia. 